\title{
Hydraulic Characteristics of Populus euphratica in an Arid Environment
}

\author{
Duan Li ${ }^{1,2}$, Jianhua Si ${ }^{1,2, *}$, Xiaoyou Zhang ${ }^{1,2}$, Yayu Gao ${ }^{1,2}$, Chunlin Wang ${ }^{1,2}$, Huan Luo ${ }^{1,2}$, \\ Jie Qin ${ }^{1,2}$ and Guanlong Gao ${ }^{3}$ \\ 1 Key Laboratory of Eco-hydrology of Inland River Basin, Northwest Institute of Eco-Environment and \\ Resources, Chinese Academy of Sciences, Lanzhou 730000, China; liduan@lzb.ac.cn (D.L.); \\ zhangxy@lzb.ac.cn (X.Z.); gaoyayu18@mails.ucas.ac.cn (Y.G.); chunlinw@lzb.ac.cn (C.W.); \\ huanluo@lzb.ac.cn (H.L.); qinjie18@mails.ucas.ac.cn (J.Q.) \\ 2 University of Chinese Academy of Sciences, Beijing 100049, China \\ 3 Department of Environment and Resources, Shanxi University, Taiyuan 030006, China; \\ gaoguanlong@sxu.edu.cn \\ * Correspondence: jianhuas@1zb.ac.cn; Tel.: +86-153-8361-9116
}

Received: 10 April 2019; Accepted: 7 May 2019; Published: 10 May 2019

\begin{abstract}
Stable hydraulic conductivity in forest trees maintains healthy tree crowns and contributes to productivity in forest ecosystems. Drought conditions break down this relationship, but the mechanisms are poorly known and may depend on drought severity. To increase the understanding of changes in hydraulic conductivity during drought, we determined hydraulic parameters in Populus euphratica Oliv. (P. euphratica) in naturally arid conditions and in a simulated severe drought using a high-pressure flow meter. The results showed that leaf-specific hydraulic conductance (LSC) of leaf blades was less variable in mild drought, and increased significantly in severe drought. Plants attempted to maintain stability in leaf blade LSC under moderate water stress. In extreme drought, LSC was enhanced by increasing hydraulic conductance in plant parts with less hydraulic limitation, decreasing it in other parts, and decreasing leaf area; this mechanism protected the integrity of water transport in portions of tree crowns, and induced scorched branches and partial mortality in other parts of crowns. We conclude that limitation in water supply and elastic regulation of hydraulic characteristics may drive the mortality of tree branches as a result of severe drought. Evaluation of adaptive water transport capacity in riparian plants in arid areas provides a scientific basis for riparian forest restoration.
\end{abstract}

Keywords: Populus euphratica; riparian tree; hydraulic characteristic; hydraulic segmentation; survival strategy; drought

\section{Introduction}

River basins in the arid inland region of China exhibit downstream oases formed by riparian forests. Populus euphratica Oliv. (P. euphratica), a dominant riparian tree species, plays a vital role in maintaining ecosystem functions in these oases [1-3]. However, extensive branch scorching and mortality are commonly found in the crowns of otherwise healthy P. euphratica trees, indicating a degrading ecological function. The reasons for canopy mortality are unclear, but may be related to water transport within the trees and how that changes in drought conditions.

The flow of water through plants has important effects on plant hydraulics, growth, structure, function, and ecology [4]. Past studies have shown that hydraulic properties are related to plant drought resistance [5]. Plant responses to drought include combinations of characteristics that allow plants to cope; these are xylem cavitation, morphological characteristics, photosynthetic responses, 
and hydraulic conductance [6]. An important feature of the survival and normal growth of a plant in an oasis environment that fluctuates from dry to wet is the adjustability and the ability to sustain effective hydraulic conductance under drought stress $[7,8]$. Because hydraulic conductance is a critical factor affecting plant performance in an adverse water environment, it can successfully predict the degree of canopy mortality in some species $[9,10]$.

Research on variability in hydraulic conductance can provide additional information on the coordination of hydraulic functional traits, and on plant ecological strategy to survive or exhibit normal growth in water-deficit conditions [11]. Hydraulic conductance is highly variable and dynamic during the plant life cycle, with different plant parts exhibiting their own water transferability [12].

In addition to absolute hydraulic conductance, water transfer efficiency expressed by leaf-specific hydraulic conductance, is an important index of water supply capacity per leaf area defining water supply to the evaporating surfaces $[13,14]$. The ability of plants to supply water to their leaves is ultimately linked with survival, therefore, leaf-specific hydraulic conductance can directly affect plant competition. The hydraulic segmentation hypothesis indicates that distal plant parts should be more vulnerable to cavitation than stems; in that, the hypothesis highlights the distribution of relative hydraulic resistance (inverse of conductance) in woody plants, and reflects the hydraulic contribution of each part to whole-plant hydraulics [15].

Previous studies of P. euphratica have failed to demonstrate the change of plant hydraulic capacity during the growing season. There is also no evidence for the coordination of water transport capacity among plant organs in P. euphratica. However, research on hydraulic conductance has been generally conducted on sections of specific plant parts (e.g., stems, leaves, shoots) in isolation from each other $[16,17]$. We know that water supply from roots to leaves depends on the integrity of flow in the xylem [18]. Accordingly, changes in hydraulic conductance measured in sections of specific parts cannot explain those observed in intact parts. Hydraulic conductance of the roots can undergo changes independently of shoots due to the lower vulnerability and stronger water absorption in roots than in shoots $[19,20]$. Moreover, available water moving from roots to the top branches must overcome greater gravity resistance than the lower parts, so leafy twigs, as the most peripheral plant parts, are vulnerable to negative water potentials experienced as hydraulic bottlenecks [21]. Therefore, both hydraulic characteristics of the whole plant and of leafy twigs at the terminal need to be examined simultaneously to explain the presence of canopy mortality branches caused by water deficiency.

To address hydraulic variability in naturally arid and severe drought conditions in P. euphratica, we measured hydraulic properties in live plant parts and simulated plant dehydration. We aimed to answer the following questions: (1) How do hydraulic characteristics vary with tree characteristics? (2) What is the variability in hydraulic contributions of individual tree parts to the total? (3) How do hydraulic characteristics change under water stress? We hypothesized that hindered water transport from roots to shoots is responsible for the mortality of branches in crown tops of otherwise healthy P. euphratica, and that the variability in hydraulic characteristics in some parts of the tree affects the ability of top branches—or even the whole plant—-to transport water in years of extreme drought.

\section{Materials and Methods}

\subsection{Study Sites}

Our study was conducted in the Alxa Desert Eco-hydrology Experimental Research Station of The Chinese Academy of Sciences, located in the lower reaches of the Heihe River Basin, in northwestern China $\left(42^{\circ} 01^{\prime} \mathrm{N}, 100^{\circ} 21^{\prime} \mathrm{E}\right.$, altitude $\left.883.54 \mathrm{~m}\right)$. The research area is one of the typical hyper-arid regions of China, exhibiting severe salinization and desertification. Local groundwater originates mainly from discharge water from the middle and upper reaches of the river [17]. Annual average temperature is $8.2{ }^{\circ} \mathrm{C}$, and annual precipitation is $38 \mathrm{~mm}$, of which $75 \%$ occurs between June and August. In this area, annual evaporation exceeds $3390 \mathrm{~mm}$ and surpasses precipitation by a factor of 90 . The soil in the area is derived from fluvial sediment, with gray-brown desert sediments [22]. 


\subsection{Plant Materials}

Populus euphratica saplings were used to examine the temporal-spatial characteristics of hydraulics. Saplings of P. euphratica were grown in a nursery for about one and a half years before they were transplanted into the field. About two hundred saplings were originally transplanted to the research station area in the middle of April 2017 in the naturally arid conditions. Saplings were planted at a spacing of about $50-60 \mathrm{~cm}$ to ensure that roots remained independent of each other. We chose 60 saplings at $2-3$ years of age that were healthy, straight, non-stressed, and growing well in 2018. Main stems were excised from roots at $3 \mathrm{~cm}$ above the ground, and one or two branches (2-3 $\mathrm{mm}$ in diameter, $80 \mathrm{~mm}$ in length) were obtained from each main stem for measurements.

\subsection{Measurement of Hydraulic Conductance}

We determined hydraulic conductance $\left(k, \mathrm{~kg} \mathrm{~s}^{-1} \mathrm{MPa}^{-1}\right)$ with the water perfusion method and a high-pressure flow meter (HPFM-GEN3, Dynamax Inc., Houston, USA) [23]. The HPFM consists of an apparatus forcing distilled water into the base of the root system or into the shoot, and measuring the corresponding flow simultaneously; hydraulic conductance is then obtained from a relationship between applied pressure and flow rate. Flow measurements in the root system were made with the HPFM operating in the "transient mode", with pressure rapidly increasing from 0 to $500 \mathrm{kPa}$; values were then calculated from the slope of the linear regression. Flow measurements in the shoot system were made with the HPFM operating in the "steady mode" with stable pressure of $350 \mathrm{kPa}$ until the rate of water flow entering the shoot stabilized. Each sequence of flow measurements lasted about 10 minutes. Data were corrected by an operating system for a reference temperature of $25^{\circ} \mathrm{C}$ to compensate for changes in water viscosity due to differences in measurement temperatures [23]. Monthly measurements of $k$ were determined at 06:00, 10:00, 14:00, 18:00, and 24:00 h from June to September on typical sunny days for three independent plants at a time.

Hydraulic conductance of the whole-shoot $\left(k_{\text {shoot }}\right)$ and whole-root $\left(k_{\text {root }}\right)$ was measured in the field when whole-shoots were excised from roots for the 60 saplings. The ends of whole-shoots and whole- roots were attached to the instrument to determine $k_{\text {shoot }}$ and $k_{\text {root }}$, respectively. Then, one or two branches obtained from each whole-shoot were enclosed in dark plastic bags with wet towels, and immediately transported to the laboratory. The bases of branches were re-cut under water to prevent air from entering into the xylem. Leaf blades were removed to obtain new hydraulic conductance values. The following measurements were performed after detaching the petioles, current-year shoots, and finally, one-year shoots.

Leaf hydraulic conductance is an integral measure of total-leaf transpiration flow-paths from the petiole-leaf junction to evaporation points [24]. Hydraulic conductance of leaf blades $\left(k_{l}\right)$ was calculated on the basis of Ohm's law hydraulic pressure analog, as follows [25]:

$$
k_{l}=\left(k_{b}^{-1}-k_{c+x+p^{-1}}\right)^{-1}
$$

where $k_{b}$ was the hydraulic conductance of a fully-leaved branch, and $k_{c+x+p}$ was the hydraulic conductance of a bare branch with petioles. Hydraulic conductance of the petiole $\left(k_{p}\right)$ was calculated as:

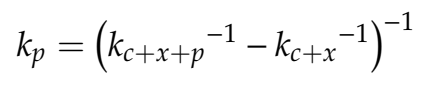

where $k_{c+x}$ was the hydraulic conductance of the bare branch. Hydraulic conductance of current-year shoots $\left(k_{c}\right)$ was calculated as:

$$
k_{c}=\left(k_{c+x}{ }^{-1}-k_{x}^{-1}\right)^{-1}
$$

where $k_{x}$ was the hydraulic conductance of a one-year shoot, measured directly.

Hydraulic segmentation represented by the hydraulic resistance ratio $(R, \%)$ could reflect the hydraulic contribution of each part, which was calculated with the hydraulic resistance $(1 / k)$ of each 
part as a percentage of the total. The measured hydraulic conductance was adjusted to the total leaf area to obtain leaf-specific hydraulic conductance (LSC, $\mathrm{kg} \mathrm{s}^{-1} \mathrm{MPa}^{-1} \mathrm{~m}^{-2}$ ). In addition, the calculation method of the total leaf area is described below.

\subsection{Tree Characteristics}

Tree characteristics were determined along with hydraulic conductance. The tree height of 60 trees was measured with a steel measuring tape before the measurement of hydraulic conductance. After the whole-shoot/root hydraulic conductance was measured, the diameter at the tree base was measured with a digital caliper in two perpendicular directions; then the xylem cross-sectional area was calculated as a circular area given the very small portion of the core material of saplings. Total leaf area was estimated from total leaf biomass and specific leaf weight (SLW, leaf area/biomass) without petiole. Ten leaves were obtained from each of the 60 saplings for this purpose. These leaves were pasted on grid paper to draw the outline. We counted the number of grids in which leaf covered $>50 \%$ of the grid area. Then, leaf area was calculated by the number of grids multiplied by the area of a single grid. Leaves were then dried at $80^{\circ} \mathrm{C}$, and weighed on an electronic balance to obtain biomass and SLW (leaf area/biomass) of each tree. Finally, total leaf area was determined by adding dry weights of all leaves assuming the same SLW for each individual tree [20]. Huber value (HV) as a hydraulic structural parameter was calculated as the cross-sectional area of xylem divided by leaf area supported by the shoot.

\subsection{Measurement of Water Status}

A nitrogen-driven pressure chamber (PMS Instruments, Corvallis, Oregon, USA) was used to measure water potential ( $\Psi_{x}, \mathrm{MPa}$ ) of small shoots $(2-3 \mathrm{~mm}$ in diameter, $80 \mathrm{~mm}$ in length). The shoots were excised from the middle of the canopy between the hours 13:00-14:00 using a sharp blade. The $\Psi_{x}$ was determined in the presence of foliage; leaves were sealed with aluminum foil and encased with a plastic bag to prevent transpiration [26]. The $\Psi_{x}$ was recorded when the first drop of xylem sap flow was observed emerging from the cut end of the shoot. Measurements were repeated using six samples taken from different trees.

\subsection{Dehydration Treatment}

To simulate an extremely dry environment, 30 leafy shoots obtained from 10 trees were collected at noon in a day for a dehydration treatment. Those shoots were enclosed in dark plastic bags with wet towels, then transported to the laboratory. These branches were then exposed to the air horizontally on a test bench for dehydration treatments lasting about $0,0.5,1,2,4$, and $6 \mathrm{~h}$ to develop a series of decreasing water potentials. We used 3-6 branches in each treatment duration. Then both hydraulic conductance and water potential were simultaneously determined.

Immediately following the dehydration treatment, we measured net photosynthesis $(\mathrm{A}, \mu \mathrm{mol}$ $\mathrm{CO}_{2} \mathrm{~m}^{-2} \mathrm{~s}^{-1}$ ) and transpiration $\left(\mathrm{E}, \mathrm{mmol} \mathrm{H}_{2} \mathrm{O} \mathrm{m}^{-2} \mathrm{~s}^{-1}\right)$ using a LI-6400 portable photosynthesis system (LI-COR, Lincoln, Nebraska, USA). We used three fully-elongated leaves on each shoot for the measurements. LI-COR settings were $1200 \mu \mathrm{mol} \mathrm{m}^{-2} \mathrm{~s}^{-1}$ for light intensity (with 6400-02B red-blue LED Light Source), and $400 \mu \mathrm{mol} \mathrm{mol}{ }^{-1}$ for $\mathrm{CO}_{2}$ concentration (using 6400-01 $\mathrm{CO}_{2}$ mixer). Corresponding water use efficiency (WUE, $\mu \mathrm{mol} \mathrm{CO}_{2} \mathrm{mmol} \mathrm{H}_{2} \mathrm{O}^{-1}$ ) under severe water stress was estimated as the ratio between $\mathrm{A}$ and $\mathrm{E}$.

\subsection{Meteorological Data}

Measured meteorological variables, including relative humidity $(\mathrm{RH}, \%)$ and air temperature $\left(\mathrm{T}_{\mathrm{a}}\right.$, ${ }^{\circ} \mathrm{C}$ ) were recorded from June to September using a Zeno-3200-A-D Data Logger every 60 minutes. 


\subsection{Data Treatment and Statistical Analysis}

Analysis of variance (ANOVA) was performed to test for differences in hydraulic values of different plant parts (e.g., whole-root/shoot, leaf blades, petiole, current-year shoot, and one-year shoot) based on post hoc means using the least significant difference test (LSD). Regression analysis between hydraulic parameters and tree characteristics was performed. Regression analysis was also used with xylem water potential of the dehydration treatment and hydraulic parameters and water use efficiency. Pearson product moment correlation was selected to test the statistical significance of correlations between these parameters. A probability value of $p<0.05$ was used to indicate statistically significant differences. Meteorological data were analyzed using time series analysis. Data were presented as means with standard error, and statistically analyzed using SPSS 19.0. Figures were plotted using Origin 8.0.

\section{Results}

\subsection{Relationships of Hydraulic Conductance with Tree Parameters}

There was no relationship between whole-root hydraulic conductance $\left(k_{\text {root }}\right)$ and ecological variables $(p>0.05)$. On the contrary, $k_{\text {shoot }}$ was highly significantly correlated with total leaf area, plant height, basal stem diameter, and xylem cross-sectional area $(p<0.01)$. Total leaf area had the greatest influence on $k_{\text {shoot }}\left(R^{2}=0.579\right.$, Figure $\left.1 \mathrm{a}\right)$, while xylem cross-sectional area had the smallest influence $\left(\mathrm{R}^{2}=0.278\right.$, Figure $\left.1 \mathrm{~d}\right)$. Correlation coefficients between $k_{\text {shoot }}$ and plant height and basal stem diameter were 0.409 and 0.349 , respectively (Figure $1 b, c)$. This indicated that water conductivity was higher in trees that were taller and had larger diameters; the regulation of leaf biomass had the greatest effect on whole-shoot conductance for the same tree.
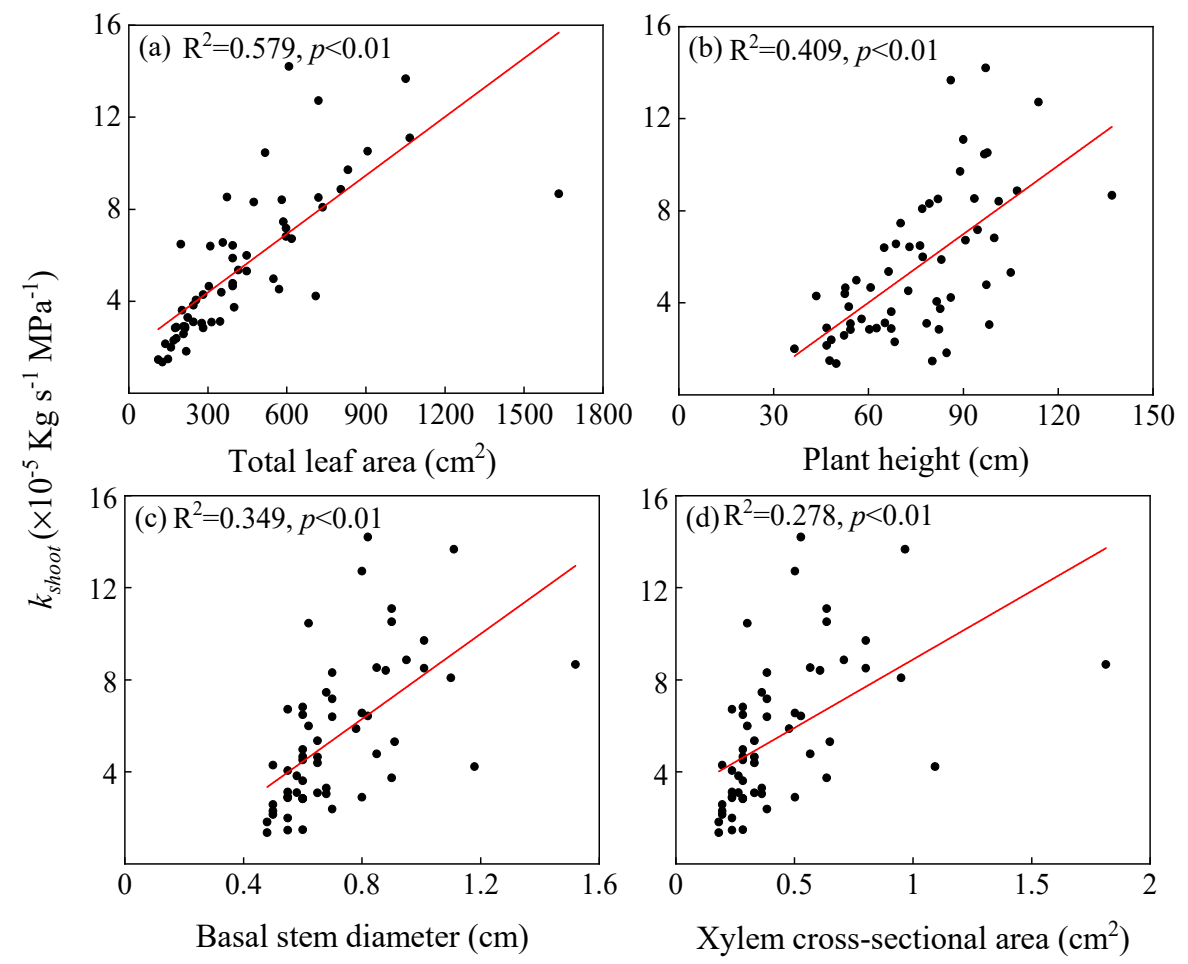

Figure 1. Regression relationships of whole-shoot hydraulic conductance $\left(k_{\text {shoot }}\right)$ and ecological variables: (a) total leaf area, (b) plant height, (c) basal stem diameter, and (d) xylem cross-sectional area. All regressions shown were statistically significant $(p<0.01)$.

Huber value (HV) changed considerably in different months, with a significant increase between July and September $(p<0.01$, Figure 2c). The single-tree trends in HV indicated that the total leaf area 
decreased from July to September, and that leaf growth peaked in June and July. Due to relatively high precipitation and low daily average temperature (Figure 2a,b), leaf senescence occurred in August, and September was the end of the leaf growing season.
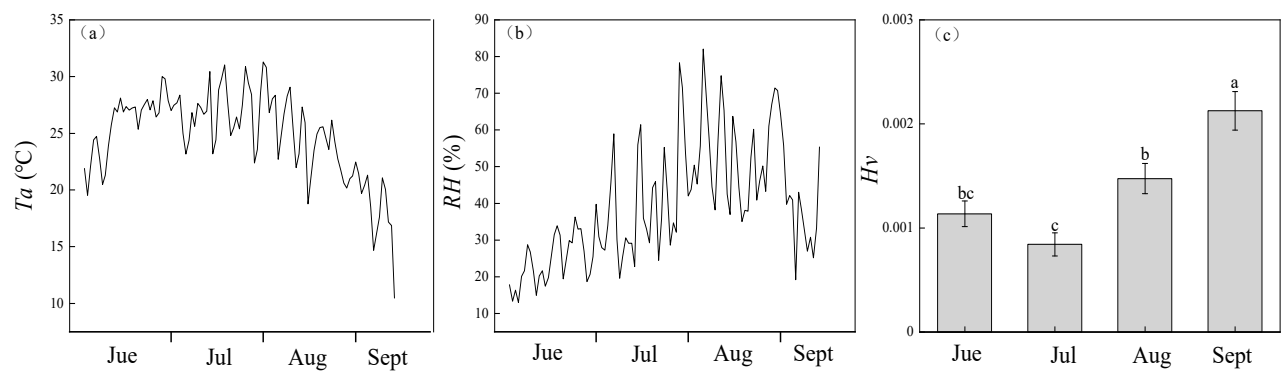

Figure 2. (a) Variability in daily mean temperature $\left(\mathrm{T}_{\mathrm{a}},{ }^{\circ} \mathrm{C}\right)$ and $(\mathbf{b})$ daily mean relative humidity (RH, $\%)$, and (c) seasonal change in Huber value (HV). Lower-case letters denote significance levels from Analysis of variance (ANOVA) based on post hoc means using least significant difference test (LSD) analysis $(p<0.05)$. Data in (c) are means with standard error.

\subsection{Characteristics of Hydraulic Segmentation}

The differences in hydraulic segmentation at different times of the day were not statistically significant $(p>0.05)$. The differences in hydraulic segmentation across months were highly significant $(p<0.01)$. The hydraulic resistance ratio of the whole-shoot $\left(R_{s}\right)$ was about $60 \%-82 \%$, which was much larger than that of the whole-root $\left(R_{r}\right) . R_{s}$ increased from June to August and then decreased from August to September; that trend was reversed for $R_{r}$ (Figure 3a). The root contribution to hydraulic resistance $\left(R_{r}\right)$ had the same trend as twig water potential. Water potential was lower in July and August and higher in June and September, with a decreasing, and later, increasing trend (Figure 4).

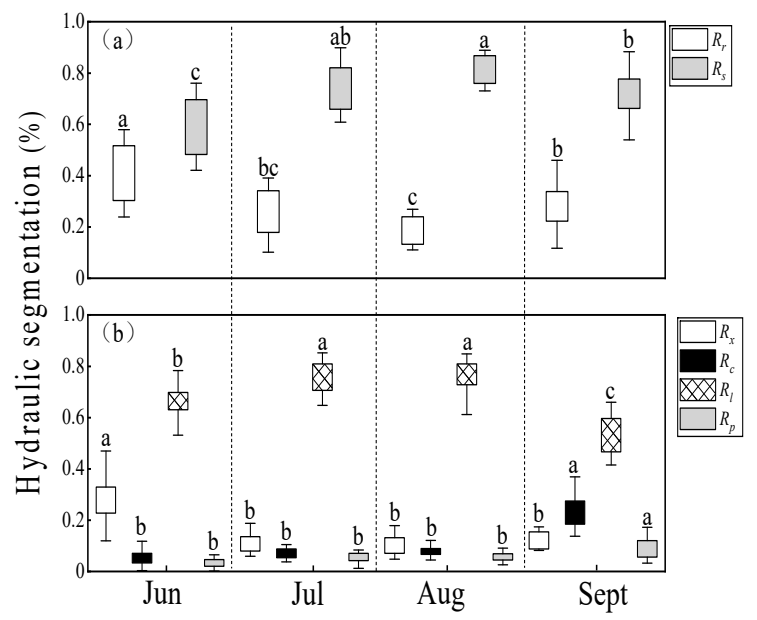

Figure 3. Seasonal changes in hydraulic segmentation for (a) whole-root/shoot and (b) parts of the leafy branch. (a): $R_{r}$ (open boxes) indicates hydraulic resistance ratio for whole-roots, $R_{S}$ (light-shaded boxes) for whole shoots. (b): $R_{x}$ (open boxes) indicates hydraulic resistance ratio for one-year shoots, $R_{c}$ (dark-shaded boxes) for current-year shoots, $R_{l}$ (cross-hatched boxes) for leaf blades, and $R_{p}$ (light-shaded boxes) for petioles. Lower-case letters over the bars denote significance levels based on ANOVA post hoc means using LSD analysis $(p<0.05)$.

The order of hydraulic segmentation from largest to smallest for different plant parts was as follows: leaf blades, shoots, and petioles. The hydraulic resistance ratio of leaf blades $\left(R_{l}\right)$ was about $50 \%-76 \%$, noticeably more than that of the other parts in each month. The hydraulic resistance ratio of current-year shoots $\left(R_{c}\right)$ and petioles $\left(R_{p}\right)$ increased respectively from $8 \%$ and $6 \%$ in June to August to $24 \%$ and $11 \%$ in September. On the contrary, one-year shoots $\left(R_{x}\right)$ exhibited a notable decline in 
hydraulic resistance ratio from $28 \%$ to $12 \%$ in July, with little change in the other months. The hydraulic resistance ratios of one-year shoots $\left(R_{x}\right)$ were higher than those of current-year shoots $\left(R_{c}\right)$, and those of petioles $\left(R_{p}\right)$ and $R_{c}$ stabilized before the end of leaf growth. However, at the end of leaf growth, $R_{c}$ and $R_{p}$ sharply increased and eventually $R_{c}$ exceeded $R_{x}$ (Figure $3 \mathrm{~b}$ ). This indicated that roots played the role with less hydraulic limitation and leaves were the parts with the greatest hydraulic limitation of the branches.

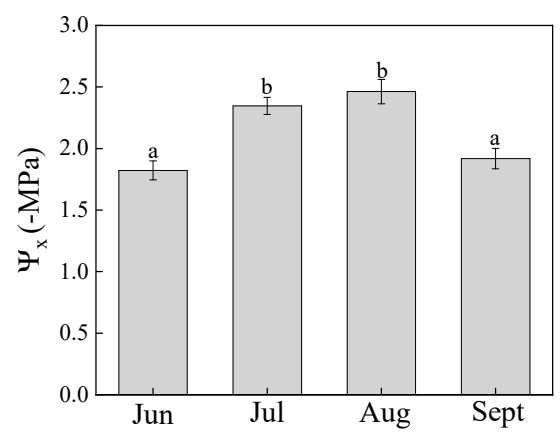

Figure 4. Change in twig water potential $\left(\Psi_{x}\right)$. Lower-case letters denote significance levels based on ANOVA post hoc means using LSD analysis $(p<0.05)$. Data are means with standard error.

Hydraulic conductance of whole-roots $\left(k_{\text {root }}\right)$ increased with increasing $k_{\text {shoot }}\left(\mathrm{R}^{2}=0.222, p<0.05\right.$, Figure 5a). Hydraulic conductance of one-year $\left(k_{x}\right)$ and current-year shoots $\left(k_{c}\right)$ was highly significantly and positively correlated with the hydraulic conductance of leaf blades $\left(k_{l}\right)$ and petioles $\left(k_{p}\right)$, with correlation coefficients of 0.335 and 0.630 , respectively $(p<0.01$, Figure $5 b, c)$. Variability in water transfer capacity in the leaf was in accordance with one-year shoots, and that in the petioles was in accordance with current-year shoots.
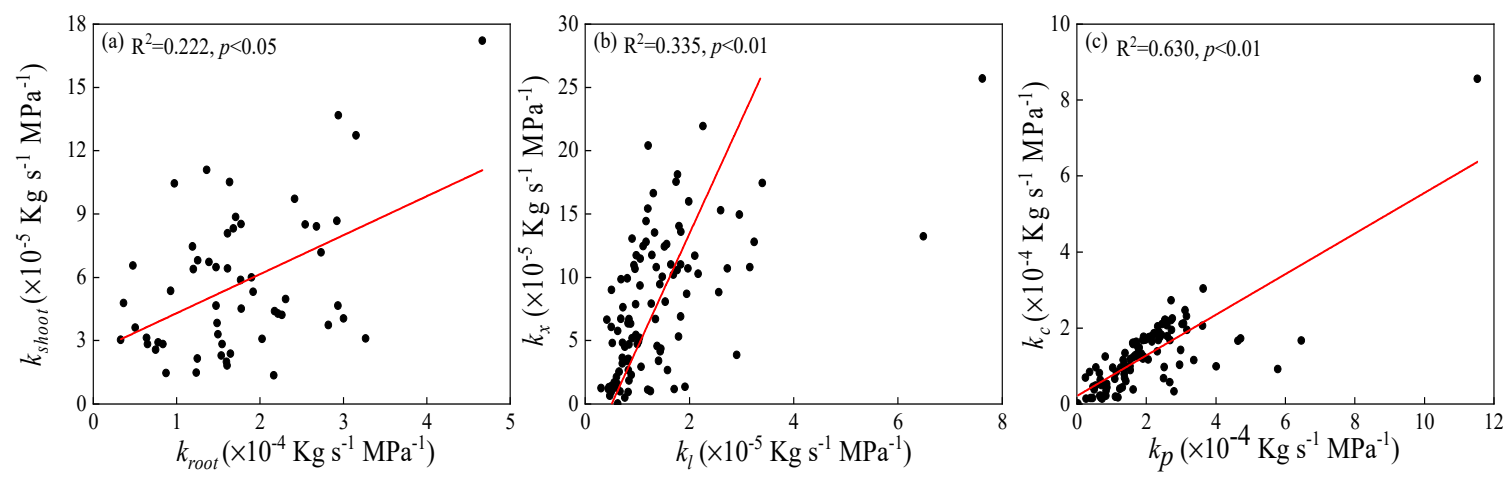

Figure 5. Regression analysis of hydraulic conductance of specific plant parts. (a) whole-roots $\left(k_{\text {root }}\right)$ and whole-shoots $\left(k_{\text {shoot }}\right)$; $(\mathbf{b})$ leaf blades $\left(k_{l}\right)$ and one-year shoots $\left(k_{x}\right)$; and $(\mathbf{c})$ petioles $\left(k_{p}\right)$ and current-year shoots $\left(k_{c}\right)$. All regressions shown were highly significant $(p<0.05)$.

\subsection{Characteristics of Leaf-Specific Hydraulic Conductance (LSC)}

Strong diurnal trends in LSC were absent in all parts of the plant $(p>0.05)$, while the effect of the month was significant $(p<0.05)$. LSC of whole-shoots $\left(k_{s l}\right)$ remained stable across consecutive months (Figure $6 \mathrm{~b}$ ). Unlike $k_{s l}$, LSC of whole-root $\left(k_{r l}\right)$ remained stable until it markedly increased in August (Figure 6a). Most notably, there was a small monthly change in LSC of leaf blades $\left(k_{l l}\right)$. The value was about $1.14( \pm 0.09) \times 10^{-3} \mathrm{~kg} \mathrm{~s}^{-1} \mathrm{MPa}^{-1} \mathrm{~m}^{-2}$ (Figure 6e). LSC of current-year shoots $\left(k_{c l}\right)$ did not change until a notable decrease in September (Figure 6d). LSC of one-year shoots $\left(k_{x l}\right)$ increased from June to July, and then stabilized (Figure 6c). Moreover, LSC of petioles $\left(k_{p l}\right)$ decreased from July to September (Figure 6f). This indicated that changes in LSC in other plant parts occurred to ensure relative stability of LSC in leaf blades, which maintained a stable water supply per leaf area. 

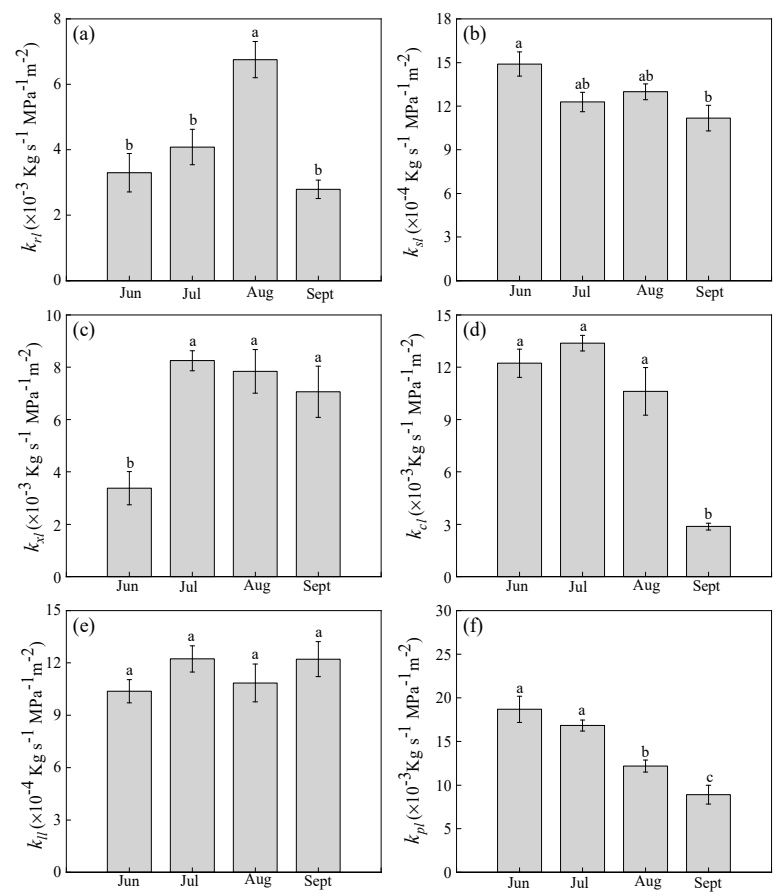

Figure 6. Seasonal changes in leaf-specific conductance (LSC) of (a) whole-roots $\left(k_{r l}\right),(\mathbf{b})$ whole-shoots $\left(k_{s l}\right),(\mathbf{c})$ one-year shoots $\left(k_{x l}\right),(\mathbf{d})$ current-year shoots $\left(k_{c l}\right),(\mathbf{e})$ leaf blades $\left(k_{l l}\right)$, and (f) petioles $\left(k_{p l}\right)$. Lower-case letters denote significance levels based on ANOVA post hoc means using LSD analysis $(p<0.05)$. Data are means with standard error.

LSCs of both leafy branches and leaf blades showed a highly negative correlation with xylem water potential $\left(\Psi_{x}\right)$ after dehydration treatments $(p<0.01$, Figure $7 \mathrm{a}, \mathrm{b})$. LSC of leaf blades $\left(k_{l l}\right)$ increased with increasing LSC of leafy branches $\left(k_{b l}\right)\left(R^{2}=0.97, p<0.01\right.$, Figure $\left.7 c\right)$. Water use efficiency (WUE) increased with a decrease in xylem water potential $\left(\Psi_{x}\right)\left(\mathrm{R}^{2}=0.439, p<0.01\right.$, Figure $\left.7 \mathrm{~d}\right)$. This demonstrated that leaf blades acted as the restriction point and limitation of the water supply had a great effect on both hydraulic regulation and water use efficiency under severe drought.
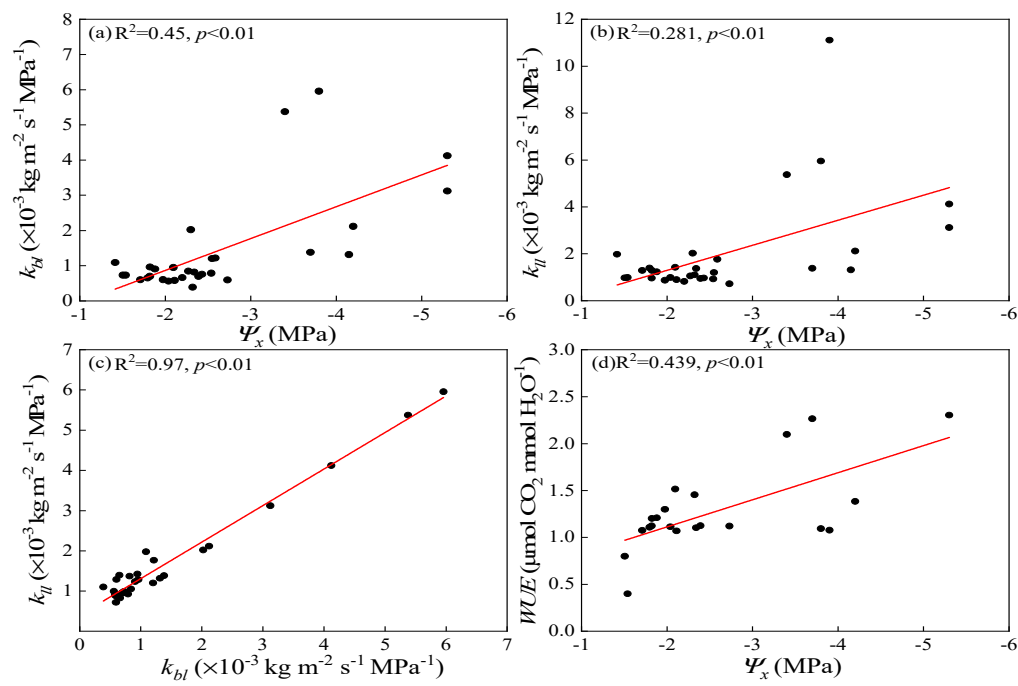

Figure 7. Regression analysis for dehydration treatments: (a) twig water potential $\left(\Psi_{x}\right)$ and LSC of leafy branches $\left(k_{b l}\right),(\mathbf{b})$ twig water potential $\left(\Psi_{x}\right)$ and LSC of leaf blades $\left(k_{l l}\right),(\mathbf{c})$ LSC of leafy branches $\left(k_{b l}\right)$ and LSC of leaf blades $\left(k_{l l}\right)$, and $(\mathbf{d})$ twig water potential $\left(\Psi_{x}\right)$ and water use efficiency (WUE). All regressions shown were highly significant $(p<0.01)$. 


\section{Discussion}

\subsection{Effects of Tree Characteristics on Hydraulics}

In our study, $k_{\text {shoot }}$ strengthened with increases in total leaf area, plant height, basal stem diameter, and xylem cross-sectional area. Hydraulic conductance is the most commonly used parameter of pressure gradient, calculated as the ratio of velocity of water flow in the plant stem to the pressure gradient. Typically, velocity of water flow in the stem increases with increasing stem diameter-increasing water transport capacity as a result [27-29]. Tall trees often have large stem diameters and large shoots. Large shoots maintain large transport areas and provide higher water flux; therefore, a positive relationship between the dimension of shoots and water transport capacity is a universal law $[15,30]$. More leaves require the enhancement of shoot capacity for transpiration, and a greater water transport capacity. Thus, for different trees, the more biomass or the larger the tree trunks, the greater the water conductivity. Within a tree, changes in leaf biomass can have the greatest effect on whole-shoot conductance, and whole-plant conductance.

\subsection{Hydraulic Contributions of Individual Tree Parts to the Total}

Roots are considered to be a restraining link in the soil-plant-atmosphere continuum. Root resistance accounted for $20 \%$ to $90 \%$ of the resistance of the whole plant [31]. Previous research showed that $k_{\text {root }}$ was typically the lowest among all of the water transport components in grapevine; root resistance accounted for $66 \%$ of the resistance in maple trees (Acer saccharinum) [31,32]. In this study, $k_{\text {root }}$ was much greater than $k_{\text {shoot }}$, with values one order of magnitude larger. The root system is the main facilitator of water transport in plants in desert areas, due to strong water absorption [33]. Though $k_{\text {root }}$ lacked strong relationships with tree characteristics of plants, $k_{\text {root }}$ was significantly related to $k_{\text {shoot }}$, which is highly correlated with tree characteristics. The purpose of hydraulic efficiency in plants is to meet their evaporation demand [25]. Enhancement of water transfer capacity in shoots requires a corresponding enhancement of water transfer capacity in roots. The hydraulic resistance contribution of roots $\left(R_{r}\right)$ exhibited the same trend as the twig water potential. That is, water transferability of the root system was consistent with the degree of water stress. Studies have shown that low water potential can force plants to enhance root hydraulic conductance in order to absorb more water. Consequently, plants tended to control root water uptake against water deficit conditions by regulating root hydraulic conductance [34]. This indicates that root hydraulic characteristics play an important role in plant adaptation or resistance to drought.

We found clear evidence that the major hydraulic resistance in P. euphratica was concentrated in leaf blades. Earlier research has shown that leaf resistance contributed approximately $30 \%-80 \%$ to total plant resistance $[14,35]$. As a result, defoliation has a great effect on hydraulic characteristics of plants, driven by decreased resistance following leaf removal. The resistance in petioles was the smallest among the tested plant parts, and this can be expected given the short distance of water transport in petioles. The change in water transfer capacity in the leaf was consistent with that in one-year shoots, and the variability in water transfer capacity in petioles was consistent with that of current-year shoots. Leaf blades and petioles had different rules of change in $k$, reflecting results of earlier studies that have shown that petiole hydraulic conductance can undergo changes regardless of the lamina [36]. At the end of leaf growth, the hydraulic resistance ratios of current-year shoots $\left(R_{c}\right)$ sharply increased and eventually became the highest. The decrease in $k$ could directly reflect the level of cavitation and embolization of xylem vessels [37]. The progressive decrease in petiole conductance could be associated with partial cavitation in petioles. Similarly, if current-year shoots (and petioles on these shoots) were more vulnerable to cavitation, conductance may be reduced there first. The decrease in the hydraulic resistance ratio of the leaf blade indicated that the contribution of the leaf blade to the complete hydraulic conductance was enhanced, and the leaf blade was less vulnerable than the petiole and the current-year shoot induced by cavitation. Inevitably, current-year shoots may be the first section of branches in which xylem cavitation occurs at the end of the leaf growing season. 
Under unfavorable growth conditions, shorter-lived organs had stronger resistance than longer-lived organs according to the construction economics of plants because shorter-lived organs required less construction-economy resources and could be easily rebuilt [11]. In favorable growth conditions, plants can retain shorter-lived sections with weaker resistance; however, in adverse growth conditions, shorter-lived parts with heightened hydraulic resistance may senesce.

\subsection{Hydraulic Characteristics in Naturally Arid and Severe Drought Conditions}

Leaf-specific hydraulic conductance (LSC) did not exhibit diurnal variability, indicating that hydraulic conductance $(k)$ was independent of the light regime. This result contradicts previous reports showing that $k$ was sensitive to changes in light intensity in some plants. Previous research has found that saplings of some species grown under severe shading showed decreased $k$ responses [38-40]. This may be due to possible plant modification of hydraulic parameters with light regulation of root production [25]. Plants can form high-density veins within a large-diameter stem to satisfy their water transport demands; this response, however, needs an extended time to develop under a high-irradiance environment $[13,41]$. Consequently, light dependence of hydraulic conductance is probably not a general phenomenon, although it may be essential in some species.

LSC of whole shoot $\left(k_{s l}\right)$ remained stable in consecutive months, but whole-root LSC $\left(k_{r l}\right)$ in August increased as an exception. This resulted from high-frequency rain events in August, with approximately three times the average annual precipitation of previous years, which led to the elimination of root xylem embolisms. Consequently, $k_{r l}$ greatly increased, consistent with previous findings [42]. These results showed that the changes in $k_{r l}$ and $k_{s l}$ were independent as a result of the stronger water absorption capacity of roots than of whole shoots. Throughout the growing season, $k_{r l}$ and $k_{s l}$ remained relatively stable, except for August.

LSC of leaf blades did not differ $\left(k_{l l}\right)$ among months. This was consistent with a recent study which showed that leaf-specific conductance of ash trees remained stable, while carbon allocation to the current-year xylem decreased due to production of fewer but wider vessels in dry conditions [43]. The appearance of stable $k_{l l}$ combined with increasing HV indicated a decreasing $k_{l}$. Some authors hypothesized that the seasonal decline of $k_{l}$ was a trigger for leaf senescence, resulting in the loss of photosynthetic capacity and carbon uptake. Leaves with stems that experience decreased $k$ are often described as no longer green, or may abscise while green [44]. Carbon limitations affect petioles first, because they are nearer xylem than leaves, and then current-year shoots. Accordingly, LSC of petioles $\left(k_{p l}\right)$ decreased before the end of leaf growth, and LSC of current-year shoots $\left(k_{c l}\right)$ decreased at the end of leaf growth. This could also explain why petioles detached very easily from current-year shoots at the end of leaf growth. In contrast, LSC of one-year shoots $\left(k_{x l}\right)$ increased noticeably in the period of leaf growth and then remained stable, illustrating that one-year shoots had priority over other parts in the water supply. Low LSC is likely to amplify the effect of a water deficit [45]; a change in LSC in other parts maintains the relative stability of leaf-blade LSC for water balance in the plant.

Values of inherent $\Psi x$ reflected moderate drought stress, and $k_{l l}$ had no relationship with drought at this level of water stress $(p>0.05)$. The decrease in water potential reflected drought stress. This indicated a negative feedback mechanism for plant survival in arid areas, and P. euphratica utilized two strategies for regulating different conditions. Increased hydraulic characteristics could increase leaf water potential as an important transpiration-regulation factor, possibly by magnifying the hydraulic signal, aimed at keeping the water balance throughout the whole plant $[8,46,47]$. P. euphratica can improve its water use efficiency accompanied by an increase in hydraulic capacity when it encounters severe water shortage. More specifically, the change in $k_{l l}$ in P. euphratica demonstrated an elastic LSC coincident with a conservative strategy in relatively moderate conditions, and a bolder strategy in relatively extreme conditions [16]. Plants can adapt to challenging conditions using their adaptive functional properties, resulting in the improvement of performance [48,49]. Meanwhile, water transport strategy in severe drought stress had offered further evidence for P. euphratica survival in an extremely arid zone. 
Leaf blade LSC $\left(k_{l l}\right)$ increased with increasing LSC of leafy branches $\left(k_{b l}\right)$, demonstrating that leaf blades acted as a bottleneck, and could determine water transferability of whole branches, and even whole shoots. All plant portions were arranged in a series with each other-and water conductivity of the whole was determined by the lowest value among the components [11]. The leaves could remain turgid and functional with a more negative $\Psi_{x}$; this may prevent cells from shrinking and buffer against rapid water potential fluctuations during water stress [50,51]. Meanwhile, leaves have the capacity to initiate an alteration of aquaporins which affects whole-plant hydraulic characteristics; variability in aquaporin activity may be the vital component that exerts influence on water transport under osmotic stress conditions [52-54]. Leaf proline was an important component of aquaporins, which accumulated with an increase in drought stress; water permeability largely controlled by the activity of aquaporins during osmotic stress could alter the physiology of branches or whole shoots [55-57]. We concluded that osmotic adjustment by physiological and, possibly, biochemical substances contributes to the response of P. euphratica to a water deficit. Thus, further work is needed to elucidate intrinsic mechanisms of drought response in cells and tissues.

We hypothesized that hindered water transport from roots to shoots was responsible for the mortality of branches in crown tops of otherwise healthy P. euphratica in years of extreme drought. During extreme water stress, LSC of leaf blades was enhanced by an increase in conductance in whole shoots. Defoliation was a natural consequence because leaves provided the greatest resistance. The whole plant was affected when the whole-shoot hydraulic conductance weakened with a decrease in total leaf area, so the plants have to reduce those parts with greater hydraulic limitation. Further, parts of branches may be removed from circulation, based on their degree of hydraulic limitation. Plants could enhance hydraulic conductance of parts with less hydraulic limitation; this would entail abandoning parts with greater hydraulic limitation and limiting productivity with the aim of increasing water transport ability in remaining plant tissues. Then the ability of top branches-even the whole plant-to transport water was affected by variability in hydraulic characteristics. As a result, branch scorching and mortality may appear on apical branches.

\section{Conclusions}

The hydraulic characteristics of P. euphratica were studied based on data analysis of whole root, whole shoot, and branch components in riparian tree species. Plants strive to maintain the stability of leaf-specific hydraulic conductance (LSC) of leaf blades under mild water stress. Nonetheless, there is a negative feedback in the LSC of leaf blades in response to severe drought. Its change reflects the adaptive water supply strategy of riparian plants in arid areas in different drought stress conditions. P. euphratica enhances LSC by enhancing hydraulic conductance of parts with less hydraulic limitation and diminishing parts with greater hydraulic limitation to avoid total loss of hydraulic efficiency to survive severe drought. Generally, limitation in water supply and a corresponding response in hydraulic regulation that is aimed at plant survival may be responsible for branch scorching and mortality in P. euphratica trees during severe drought. Water transport capacity of riparian plants in arid areas in different drought stress conditions provides a scientific basis for restoration in desert riparian forests. Further research on P. euphratica should address plant physiology and anatomy to increase the understanding of internal mechanisms of drought acclimation.

Author Contributions: D.L. and J.S. collected experimental data, analyzed, and wrote the manuscript. X.Z., Y.G., C.W., H.L., J.Q. and G.G. participated equally in conceptualization, data analysis, and manuscript preparation and review.

Funding: This research was funded by the National Key R\&D Program of China (No.2016YFC0400908, 2016YFC0501009), and major science and technology project in Inner Mongolia autonomous region-Formation Mechanism and Safety Guarantee System of fragile environment in the Badain Jaran Desert.

Acknowledgments: We wish to express our thanks for the support received from the forest farm of Ejina Banner in the Alashan League. Thanks to Kathryn B. Piatek for her editorial suggestions on the spelling and grammar of the manuscript. The authors also record their sincere appreciation for the helpful and constructive comments made by reviewers of the draft manuscript. 
Conflicts of Interest: The authors declare no conflicts of interest.

\section{References}

1. Chen, Y.; Xu, C.; Li, W. Groundwater depth affects the daily course of gas exchange parameters of Populus euphratica in arid areas. Environ. Earth Sci. 2012, 66, 433-440. [CrossRef]

2. Si, J.; Feng, Q.; Cao, S.; Yu, T.; Zhao, C. Water use sources of desert riparian Populus euphratica forests. Environ. Monit. Assess. 2014, 186, 5469-5477. [CrossRef] [PubMed]

3. Wang, Q.; Ruan, X.; Chen, Y.N.; Li, W.H. Eco-physiological response of Populus euphratica Oliv. to water release of the lower reaches of the Tarim River, China. Environ. Geol. 2007, 53, 349-357. [CrossRef]

4. Hernández, E.I.; Vilagrosa, A.; Luis, V.C.; Llorca, M.; Chirino, E.; Vallejo, V.R. Root hydraulic conductance, gas exchange and leaf water potential in seedlings of Pistacia lentiscus L. and Quercus suber L. grown under different fertilization and light regimes. Environ. Exp. Bot. 2009, 67, 269-276. [CrossRef]

5. Cochard, H.; Herbette, S.; Hernández, E.; Hölttä, T.; Mencuccini, M. The effects of sap ionic composition on xylem vulnerability to cavitation. J. Exp. Bot. 2010, 61, 275-285. [CrossRef] [PubMed]

6. Pivovaroff, A.L.; Pasquini, S.C.; De Guzman, M.E.; Alstad, K.P.; Stemke, J.S.; Santiago, L.S. Multiple strategies for drought survival among woody plant species. Funct. Ecol. 2016, 30, 517-526. [CrossRef]

7. Engelbrecht, B.M.; Comita, L.S.; Condit, R.; Kursar, T.A.; Tyree, M.T.; Turner, B.L. Drought sensitivity shapes species distribution patterns in tropical forests. Nature 2007, 447, 80-82. [CrossRef]

8. Hochberg, U.; Bonel, A.G.; David-Schwartz, R.; Degu, A.; Fait, A.; Cochard, H.; Peterlunger, E.; Herrera, J.C. Grapevine acclimation to water deficit: The adjustment of stomatal and hydraulic conductance differs from petiole embolism vulnerability. Planta 2017, 245, 1091-1104. [CrossRef]

9. Anderegg, W.R.L.; Anderegg, L.D.L. Hydraulic and carbohydrate changes in experimental drought-induced mortality of saplings in two conifer species. Tree Physiol. 2013, 33, 252-260. [CrossRef]

10. McDowell, N.G.; Fisher, R.A.; Xu, C.; Domec, J.C.; Hölttä, T.; Mackay, D.S.; Sperry, J.S.; Boutz, A.; Dickman, L.; Gehres, N.; et al. Evaluating theories of drought-induced vegetation mortality using a multimodel-experiment framework. New Phytol. 2013, 200, 304-321. [CrossRef]

11. Pivovaroff, A.L.; Lawren, S.; Santiago, L.S. Coordination of stem and leaf hydraulic conductance in southern California shrubs: A test of the hydraulic segmentation hypothesis. New Phytol. 2014, 203, 842-850. [CrossRef]

12. Martin, K.C.; Bruhn, D.; Lovelock, C.E.; Feller, I.C.; Evans, J.R.; Ball, M.C. Nitrogen fertilization enhances water-use efficiency in a saline environment. Plant Cell Environ. 2010, 33, 344-357. [CrossRef] [PubMed]

13. Lawren, S.; Tyree, M.T.; Michele, H.N. Leaf hydraulic architecture correlates with regeneration irradiance in tropical rainforest trees. New Phytol. 2010, 167, 403-413.

14. Sack, L.; Holbrook, N.M. Leaf hydraulics. Annu. Rev. Plant Biol. 2006, 57, 361-381. [CrossRef] [PubMed]

15. Tyree, M.T.; Zimmermann, M.H. Xylem structure and the ascent of sap. Science 2002, 222, 500-501.

16. Pan, Y.; Chen, Y.; Chen, Y.; Wang, R.; Ren, Z. Impact of groundwater depth on leaf hydraulic properties and drought vulnerability of Populus euphratica in the Northwest of China. Trees 2016, 30, 2029-2039. [CrossRef]

17. Zhou, H.; Chen, Y.; Li, W.; Ayup, M. Xylem hydraulic conductivity and embolism in riparian plants and their responses to drought stress in desert of Northwest China. Ecohydrology 2013, 6, 984-993. [CrossRef]

18. Maherali, H.; Pockman, W.T.; Jackson, R.B. Adaptive variation in the vulnerability of woody plants to xylem cavitation. Ecology 2004, 85, 2184-2199. [CrossRef]

19. Hukin, D.; Cochard, H.; Dreyer, E.; Thiec, D.L.; Bogeat-Triboulot, M.B. Cavitation vulnerability in roots and shoots: Does Populus euphratica Oliv., a poplar from arid areas of Central Asia, differ from other poplar species? J. Exp. Bot. 2005, 56, 2003-2010. [CrossRef] [PubMed]

20. Alsina, M.M.; Smart, D.R.; Bauerle, T.; De Herralde, F.; Biel, C.; Stockert, C.; Negron, C.; Save, R. Seasonal changes of whole root system conductance by a drought-tolerant grape root system. J. Exp. Bot. 2011, 62, 99-109. [CrossRef] [PubMed]

21. Nardini, A.; Pitt, F. Drought resistance of Quercus pubescens as a function of root hydraulic conductance, xylem embolism and hydraulic architecture. New Phytol. 2010, 143, 485-493. [CrossRef]

22. Si, J.H.; Chang, Z.Q.; Su, Y.H.; Xi, H.Y.; Feng, Q. Stomatal Conductance Characteristics of Populus euphratica Leaves and Response to Environmental Factors in the Extreme Arid Region. Acta Bot. Boreali-Occident. Sin. 2008, 11, 1596-1599. 
23. Tyree, M.T.; Patiño, S.; Bennink, J.; Alexander, J. Dynamic measurements of roots hydraulic conductance using a high-pressure flowmeter in the laboratory and field. J. Exp. Bot. 1995, 46, 83-94. [CrossRef]

24. Sack, L.; Melcher, P.J.; Zwieniecki, M.A.; Holbrook, N.M. The hydraulic conductance of the angiosperm leaf lamina: A comparison of three measurement methods. J. Exp. Bot. 2002, 53, 2177-2184. [CrossRef]

25. Raimondo, F.; Trifilo, P.; Gullo, M.L.; Buffa, R.; Nardini, A.; Salleo, S. Effects of reduced irradiance on hydraulic architecture and water relations of two olive clones with different growth potentials. Environ. Exp. Bot. 2009, 66, 249-256. [CrossRef]

26. Li, Y.; Chen, W.; Chen, J.; Shi, H. Vulnerability to drought-induced cavitation in shoots of two typical shrubs in the southern Mu Us Sandy Land, China. J. Arid Land 2016, 8, 125-137. [CrossRef]

27. Becker, P.; Meinzer, F.C.; Wullschleger, S.D. Hydraulic limitation of tree height: A critique. Funct. Ecol. 2000, 14, 4-11. [CrossRef]

28. Zhang, Y.J.; Rockwell, F.E.; Wheeler, J.K.; Holbrook, N.M. Reversible Deformation of Transfusion Tracheids in Taxus baccata Is Associated with a Reversible Decrease in Leaf Hydraulic Conductance. Plant Physiol. 2014, 165, 1557-1665. [CrossRef] [PubMed]

29. Zhang, Z.L.; Liu, G.D.; Zhang, F.C.; Zheng, C.X.; Ni, F.Q.; Kang, Y.H.; Zeng, Y. Effects of nitrogen content on growth and hydraulic characteristics of peach (Prunus persica L.) seedlings under different soil moisture conditions. J. For. Res. 2014, 25, 365-375. [CrossRef]

30. Maherali, H.; Delucia, E.H. Xylem conductivity and vulnerability to cavitation of ponderosa pine growing in contrasting climates. Tree Physiol. 2000, 20, 859-867. [CrossRef] [PubMed]

31. Tsuda, M.; Tyree, M.T. Whole-plant hydraulic resistance and vulnerability segmentation in Acer saccharinum. Tree Physiol. 1997, 17, 351-357. [CrossRef] [PubMed]

32. Vandeleur, R.K.; Mayo, G.; Shelden, M.C.; Gilliham, M.; Kaiser, B.N.; Tyerman, S.D. The role of plasma membrane intrinsic protein aquaporins in water transport through roots: Diurnal and drought stress responses reveal different strategies between isohydric and anisohydric cultivars of grapevine. Plant Physiol. 2009, 149, 445-460. [CrossRef]

33. Vadez, V. Root hydraulics: The forgotten side of roots in drought adaptation. Field Crop. Res. 2014, 165, 15-24. [CrossRef]

34. Parent, B.; Hachez, C.; Redondo, E.; Simonneau, T.; Chaumont, F.; Tardieu, F. Drought and ABA effects on aquaporin content translate into changes in hydraulic conductivity and leaf growth rate: A trans-scale approach. Comp. Biochem. Physiol. Part A Mol. Integr. Physiol. 2009, 153, 2000-2012.

35. Liu, J.; Equiza, M.A.; Navarro-Rodenas, A.; Lee, S.H.; Zwiazek, J.J. Hydraulic adjustments in aspen (Populus tremuloides) seedlings following defoliation involve root and leaf aquaporins. Planta 2014, 240, 553-564. [CrossRef]

36. Prendin, A.L.; Mayr, S.; Beikircher, B.; von Arx, G.; Petit, G. Xylem anatomical adjustments prioritize hydraulic efficiency over safety as Norway spruce trees grow taller. Tree Physiol. 2018, 38, 1088-1097. [CrossRef]

37. And, M.T.T.; Sperry, J.S. Vulnerability of Xylem to Cavitation and Embolism. Annu. Rev. Plant Physiol. Plant Mol. Biol. 2003, 40, 19-38.

38. Tyree, M.T.; Nardini, A.; Salleo, S.; Sack, L.; El Omari, B. The dependence of leaf hydraulic conductance on irradiance during HPFM measurements: Any role for stomatal response? J. Exp. Bot. 2005, 56, 737-744. [CrossRef] [PubMed]

39. Voicu, M.C. Diurnal and seasonal changes of leaf lamina hydraulic conductance in bur oak (Quercus macrocarpa) and trembling aspen (Populus tremuloides). Trees 2011, 25, 485-495. [CrossRef]

40. Barigah, T.S.; Ibrahim, T.; Bogard, A.; Faivre-Vuillin, B.; Lagneau, L.A.; Montpied, P.; Dreyer, E. Irradiance-induced plasticity in the hydraulic properties of saplings of different temperate broad-leaved forest tree species. Tree Physiol. 2006, 26, 1505-1516. [CrossRef]

41. Gullo, M.A.; Raimondo, F.; Crisafulli, A.; Salleo, S.; Nardini, A. Leaf hydraulic architecture and water relations of three ferns from contrasting light habitats. Funct. Plant Biol. 2010, 37, 566-574. [CrossRef]

42. West, A.G.; Hultine, K.R.; Jackson, T.L.; Ehleringer, J.R. Differential summer water use by Pinus edulis and Juniperus osteosperma reflects contrasting hydraulic characteristics. Tree Physiol. 2007, 27, 1711-1720. [CrossRef] [PubMed] 
43. Petit, G.; Savi, T.; Consolini, M.; Anfodillo, T.; Nardini, A. Interplay of growth rate and xylem plasticity for optimal coordination of carbon and hydraulic economies in Fraxinus ornus trees. Tree Physiol. 2016, 36, 1310. [PubMed]

44. Andrea, N.; Marta, B.; Tadeja, S. Shoot desiccation and hydraulic failure in temperate woody angiosperms during an extreme summer drought. New Phytol. 2013, 200, 322-329.

45. Rust, S.; Hüttl, R.F. The effect of shoot architecture on hydraulic conductance in beech (Fagus sylvatica L.). Trees 1999, 14, 39-42. [CrossRef]

46. Lopez, D.; Venisse, J.S.; Fumanal, B.; Chaumont, F.; Guillot, E.; Daniels, M.J.; Cochard, H.; Julien, J.L.; Gousset-Dupont, A. Aquaporins and leaf hydraulics: Poplar sheds new light. Plant Cell Physiol. 2013, 54, 1963-1975. [CrossRef]

47. Else, M.A.; Coupland, D.; Dutton, L.; Jackson, M.B. Decreased root hydraulic conductivity reduces leaf water potential, initiates stomatal closure, and slows leaf expansion in flooded plantsof castor oil (Ricinus communis) despite diminished delivery of ABA from roots to shoots in xylem sap. Physiol. Plant. 2010, 111, 46-54. [CrossRef]

48. Dunbar-Co, S.; Sporck, M.; Sack, L. Leaf trait diversification and design in seven rare taxa of the hawaiian plantago radiation. Int. J. Plant Sci. 2009, 170, 61-75. [CrossRef]

49. Targetti, S.; Messeri, A.; Staglianò, N.; Argenti, G. Leaf functional traits for the assessment of succession following management in semi-natural grasslands: A case study in the North Apennines, Italy. Appl. Veg. Sci. 2013, 16, 325-332. [CrossRef]

50. Sack, L.; Cowan, P.D.; Jaikumar, N.; Holbrook, N.M. The 'hydrology' of leaves: Co-ordination of structure and function in temperate woody species. Plant Cell Environ. 2003, 26, 1343-1356. [CrossRef]

51. Sack, L.; Tyree, M.T. Vascular Transport in Plants; Academic Press: New York, NY, USA, 2005; pp. 93-114.

52. Meinzer, F.C. Co-ordination of vapour and liquid phase water transport properties in plants. Plant Cell Environ. 2002, 25, 265-274. [CrossRef]

53. Bramley, H.; Turner, D.W.; Tyerman, S.D.; Turner, N.C. Water Flow in the Roots of Crop Species: The Influence of Root Structure, Aquaporin Activity, and Waterlogging. Adv. Agron. 2007, 96, 133-196.

54. Martorell, S.; Medrano, H.; Tomàs, M.; Escalona, J.M.; Flexas, J.; Diaz-Espejo, A. Plasticity of vulnerability to leaf hydraulic dysfunction during acclimation to drought in grapevines: An osmotic-mediated process. Physiol. Plant. 2015, 153, 381-391. [CrossRef] [PubMed]

55. Maurel, C.; Simonneau, T.; Sutka, M. The significance of roots as hydraulic rheostats. J. Exp. Bot. 2010, 61, 3191-3198. [CrossRef] [PubMed]

56. Chen, Y.; Wang, Q.; Ruan, X.; Li, W.; Chen, Y. Physiological Response of Populus euphratica to Artificial Water-recharge of the Lower Reaches of Tarim River. Acta Bot. Sin. 2004, 46, 1393-1401.

57. Romero, P.; Dodd, I.C.; Martinezcutillas, A. Contrasting physiological effects of partial root zone drying in field-grown grapevine (Vitis vinifera L. cv. Monastrell) according to total soil water availability. J. Exp. Bot. 2012, 63, 4071-4083. [CrossRef]

(C) 2019 by the authors. Licensee MDPI, Basel, Switzerland. This article is an open access article distributed under the terms and conditions of the Creative Commons Attribution (CC BY) license (http://creativecommons.org/licenses/by/4.0/). 